\title{
THE ABILITY TO UNDERSTAND INDONESIAN LANGUAGE EQUIVALENTS AMONG PRIVATE UNIVERSITIES STUDENTS IN JAKARTA
}

\author{
Hilda Hilaliyah $\left.{ }^{*}\right)$ \\ Universitas Indraprasta PGRI \\ Fajar Kurniadi \\ Universitas Indraprasta PGRI \\ Tanti Dwi Oktaviany \\ Universitas Indraprasta PGRI \\ *) Correspondences author: Jalan Nangka No. 58c, Tanjung Barat, Jagakarsa, Jakarta Selatan 12530, DKI Jakarta, Indonesia; \\ e-mail: hilda.unindra@gmail.com
}

\begin{abstract}
This study aims to determine the ability of students to understand the Indonesian equivalent in using Indonesian vocabulary. The method used in this research is descriptive qualitative method. The results of this study are the low use of Indonesian equivalent words among students, it is proven that at least $98 \%$ of respondents hear and use the word Laundry more often than the word penatu. In addition, there is a lack of habituation to the use of equivalent words in the academic environment and society. This is evidenced by several words that are closely related to the academic environment and people still use words in foreign languages, even though their equivalent words have been found and socialized.
\end{abstract}

Keywords: Word Match, Indonesian Language, Student.

Article History: Received: 04/06/2021; Revised: 11/06/2021; Accepted: 11/06/2021; Published: 30/06/2021

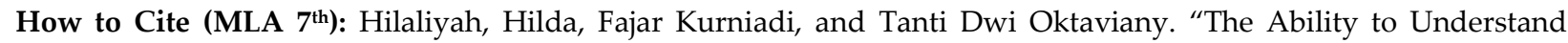
Indonesian Language Equivalents Among Private University Students in Jakarta." Hortatori Jurnal Pendidikan Bahasa dan Sastra Indonesia 5.1 (2021): 45-50. Print/Online. Copyrights Holder: Hilda Hilaliyah, Fajar Kurniadi, Tanti Dwi Oktaviany. First Publication: Hortatori Jurnal Pendidikan Bahasa dan Sastra Indonesia (2017).

This work is licensed under a Creative Commons Attribution-ShareAlike 4.0 International License.

\section{Pendahuluan}

Bahasa Indonesia mengalami perkembangan melalui pemutakhiran kosakatanya. Kosakata bahasa Indonesia terus ditambahkan dengan tujuan memperkaya khazanah bahasa Indonesia. Hal tersebut dikarenakan istilah asing masih diutamakan dalam praktik berkomunikasi, baik secara lisan maupun tulisan. Istilah tersebut memudarkan pesona bahasa Indonesia yang seharusnya diutamakan dalam kegiatan seharihari (Huda, 2019).

Pemadanan kata asing ke dalam bahasa merupakan suatu ciri khas tersendiri dari bahasa Indonesia yang tidak dimiliki oleh bahasa asing lainnya. Hal ini memungkinkan bertambahnya jumlah kosakata yang masuk ke dalam Kamus Besar Bahasa Indonesia (KBBI). Akan tetapi, sebagian masyarakat tidak mengetahui adanya bentuk pemadanan istilah dalam bahasa, termasuk di dalamnya mahasiswa.

Padanan dalam terjemahan selalu dikaitkan dengan fungsi teks dan bentuk terjemahan (Sulistyowati dalam Hudaa, 2019). Dengan kata lain, padanan muncul sebagai suatu bentuk pengganti dari istilah asing menjadi istilah bahasa Indonesia. Bentuk kata dalam padanan dapat dikatakan memiliki fungsi yang sama dengan bahasa asing, tetapi istilah yang digunakan sudah sesuai dengan kaidah bahasa Indoenesia. Untuk itu, padanan dapat menjadi alternatif istilah yang tepat dalam bahasa Indonesia.

Masuknya era digital turut memengaruhi penggunaan bahasa dalam berkomunikasi. Sebagai contoh bahasa asing dapat ditemukan di media sosial, media cetak, dan interaksi langsung. Hal tersebut tentu 
berdampak pada pudarnya pesona bahasa Indonesia sebagai bahasa nasional. Setiap orang yang datang ke Indonesia seharusnya menggunakan bahasa Indonesia agar mempelajari budaya yang terdapat di dalamnya. Akan tetapi, justru penggunaan bahasa asing lebih dominan digunakan dalam proses interaksi di masyarakat. Modernitas menjanjikan perkembangan dalam pelbagai aspek, salah satunya adalah bahasa. Namun, bahasa Indonesia yang ditargetkan sebagai bahasa internasional tidak menjadi prioritas orang Indonesia itu sendiri. Iklan dan spanduk yang berada di jalan, lebih percaya dengan bahasa pemasaran yang menggunakan bahasa Inggris. Padahal, dalam bahasa Indonesia ada istilah transliterasi dan padanan kata yang menjadikan bahasa Indonesia memiliki pengganti bahasa aslinya (Hudaa, 2017).

Chamalah (2018) mengemukakan dominasi penggunaan bahasa Inggris terhadap bahasa Indonesia menunjukkan sikap berbahasa penutur bahasa Indonesia sebagai gejala xenoglossophilia, yaitu gejala psikologi berupa kecenderungan mencintai penggunaan katakata yang aneh atau asing dengan cara tidak wajar. Dampak dari hal tersebut yaitu lunturnya bahasa dan budaya Indonesia secara perlahan disebabkan oleh banyaknya mahasiswa yang menganggap bahasa asing sebagai bahasa yang menjadi primadona dan merasa bangga dapat menggunakan bahasa asing.

Penggunaan istilah bahasa Inggris dalam kegiatan sehari-hari tanpa mengetahui padanan kata dalam bahasa Indonesia sering dijumpai di kalangan mahasiswa. Sebagai contoh, beberapa mahasiswa kerap menggunakan kata "hand sanitizer" daripada kata "penyanitasi tangan",. Hal tersebut menandai bahwa mereka lebih cenderung menggunakan istilah bahasa Inggris daripada istilah yang sudah ada padanannya dalam bahasa Indonesia.

Pengaturan penggunaan bahasa Indonesia, bahasa daerah, dan bahasa asing tertuang dalam UU RI No. 24 tahun 2009 tentang Bendera, Bahasa, dan Lambang Negara, serta Lagu Kebangsaan. Pelaksanaannya diatur dalam PP RI No. 57 Tahun 2014 tentang Pengembangan, Pembinaan, dan Perlindungan Bahasa dan Sastra, serta Peningkatan Fungsi Bahasa. Sejatinya penggunaan bahasa Indonesia, bahasa daerah, dan bahasa asing dalam kehidupan sehari-hari tidak terjadi tumpang tindih karena sudah jelas pengaturan dan pelaksanaannya berdasarkan UU dan PP tersebut. Bahkan, Peraturan Presiden No.63 Tahun 2019 tentang Penggunaan Bahasa Indonesia turut memperkuat dalam mencintai Bahasa Indonesia.

Merujuk pada deskripsi tentang penggunaan bahasa Indonesia, perlu adanya penelitian yang mendalam terkait hal ini. Tim Peneliti berupaya memperoleh data terkait kemampuan memahami padanan kata bahasa Indonesia pada kalangan mahasiswa universitas swasta di Jakarta.

Syihaabul Hudaa dengan judul Transliterasi, Serapan, dan Padanan Kata: Upaya Pemutakhiran Istilah dalam Bahasa Indonesia. Hasil penelitiannya Pemutakhiran bahasa dipengaruhi oleh perkembangan zaman dan disesuaikan dengan kaidah yang berlaku di dalam bahasa Indonesia. Istilah baru digunakan sebagai upaya pengutamaan bahasa Indonesia dalam berkomunikasi di ruang publik. Munculnya kosakata asing dan kemudian dipadankan atau diserap ke dalam bahasa Indonesia menjadi bukti bahwa bahasa Indonesia memiliki kaidah pembakuan kata yang disepakati. Kata yang sudah dimutakhirkan dapat digunakan sebagai alat berkomunikasi di masyarakat maupun di media sosial. Selain itu, bentuk transliterasi, serapan, dan padanan kata dalam bahasa Indonesia memiliki perbedaan yang dapat diamati, sehingga pengguna bahasa dapat membedakan unsurnya berdasarkan bentuk penulisannya.

Zulisih Maryani dengan judul Padanan Kata Asing-Indonesia dalam Bidang Seni dan hasil penelitiannya Padanan kata asing-Indonesia di bidang seni adalah kata atau frasa dalam bahasa asing yang memiliki kesejajaran makna dengan kata atau frasa dalam bahasa Indonesia di bidang seni. Kata asing yang dimaksudkan adalah unsur-unsur yang berasal dari bahasa asing yang masih dipertahankan bentuk aslinya karena belum menyatu dengan bahasa Indonesia. Pemadanan kata asing-Indonesia di bidang seni memerlukan penyerapan, yaitu proses pengambilan kosakata dari bahasa asing, baik bahasa asing Eropa (seperti bahasa Belanda, bahasa Inggris, bahasa Portugal), maupun bahasa asing Asia (seperti bahasa Arab, bahasa Parsi, bahasa Sansekerta, bahasa Cina). Termasuk dari bahasa-bahasa Nusantara (seperti bahasa Jawa, bahasa Sunda, bahasa Minang, bahasa Bali. Dalam buku ini dipaparkan tabel daftar padanan kata asing-Indonesia di bidang seni. Cara menyerap kata dan istilah asing ke bahasa Indonesia dalam bidang seni: (1) kata dan istilah asing dapat diserap melalui penerjemahan, misalnya pemeranan; akting dari acting; daerah pemeranan dari acting area; pelancipan dari streamlining; seni jalanan dari street art; lensa sudut lebar dari wide-angle lens; dan cahaya jendela dari window light dan (2) kata dan istilah asing juga dapat diserap melalui penyesuaian ejaan. Penyesuaian ejaan itu dilakukan dengan mengutamakan bentuk tulisannya tanpa mengabaikan lafalnya, misalnya teater epik dari epic theatre; epilog dari epilogue; kanvas dari canvas; kroma dari chroma; foto makro dari macro photo; dan fotografi makro dari macro 
photography. Alasan rendahnya frekuensi penggunaan kata dan istilah Indonesia dalam bidang seni berkaitan dengan alasan pemakaian unsur-unsur bahasa asing, yaitu: (1) kehematan, kemudahan, dan kesingkatan; (2) dorongan gengsi; (3) memenuhi kebutuhan register tertentu; dan (4) nuansa makna.

Siti Saleha Sanusi dengan judul Padanan kata kerja Bahasa Jerman: Satu analisis ketepatannya ke atas makna ayat. Hasil penelitiannya kajian ini dijalankan dengan tujuan untuk melihat ketepatan penggunaan kata kerja bahasa Jerman dalam pembentukan ayat. Dalam kajian ini, empat kategori kata kerja telah dipilih untuk dianalisis yaitu Kata Kerja Nalar, Kata Kerja Tidak Nalar, Kata Kerja Terpisah dan Kata Kerja Tidak Terpisah. Kesemua kata kerja yang dipilih merupakan kata yang diberi penekanan khusus dalam pembelajaran bahasa Jerman. Tumpuan kajian ialah untuk melihat ciri-ciri kesinoniman antara kata kerja yang digunakan responden dengan padanan kata kerja yang sepatutnya serta meninjau implikasi ketidaktepatan padanan kata kerja tersebut ke atas pembentukan makna ayat. Untuk memenuhi objektif di atas, pengkaji telah membuat satu analisis terhadap ketepatan kata kerja bahasa Jerman berdasarkan 720 ayat yang diperoleh daripada 15 buah skrip VCD pelajar-pelajar bahasa Jerman Asas (Tahap Tiga) Universiti Teknologi Mara (UiTM) Shah Alam. Penguraian setiap kata kerja adalah berdasarkan ketepatan maknanya dalam konteks penggunaan. Ayat-ayat yang menggunakan kata kerja yang dikenal pasti tidak menepati makna konteks diuraikan menggunakan kaidah kualitatif yang berorientasikan linguistik deskriptif. Kaidah kualitatif dijalankan dengan menggunakan jadual yang telah diubahsuai dari Teori Analisis Komponen Makna yang diutarakan oleh Kempson (1991) dan Loebner (2002) bagi menjelaskan ciri-ciri kesinoniman yang wujud pada setiap kata yang digunakan dengan padanan yang sepatutnya. Kajian ini telah mendapati bahwa daripada jumlah keseluruhan yaitu sebanyak 27 kata kerja yang dianalisis, 8 padanan kata adalah bersifat sinonim dengan kata kerja yang digunakan oleh responden. Ini jelas menunjukkan bahwa pilihan padanan setiap kata adalah berdasarkan ketepatannya dalam konteks ayat. Walaupun kebanyakan padanan memilki sifat sinonim dengan kata yang digunakan, namun bagi Kata Kerja Tidak Terpisah (KKTT), jumlah yang diperoleh menunjukkan bahwa hanya kata kerja tersebut tidak memiliki ciri-ciri sinonim dengan padanan kata kerja yang sepatutnya.

Alexander Sudibyo dengan judul Analisis Pemilihan Padanan Kata Science dalam Rangka Penyempurnaan Konsep RUU Keantariksaan. Hasil penelitiannya Hasil penilaian numerik terhadap ketiga alternatif tersebut menjadi ilmu pengetahuan 5, ilmu 11, dan Sains 8. Berdasar nilai numerik tersebut, dapat disimpulkan bahwa yang memiliki tingkat kebaikan dan kebenaran tertinggi adalah terminologi 'ilmu' yaitu 11. Atas penilaian ini maka disarankan terminologi yang dipergunakan dalam RUU Keantariksaan adalah 'ilmu' sebagai padanan kata dalam bahasa Inggris 'science' dan scientific knowledge.

Endang Wiyanti dengan judul Kemampuan Memahami Padanan Kata Bahasa Indonesia pada Peserta Kuis Olimpiade Indonesia Cerdas Season 2 di Rajawali Televisi. Hasil penelitiannya Kemampuan pemahaman padanan kata dalam bahasa Indonesia pada peserta kuis Olimpiade Indonesia Cerdas di bawah standar rata-rata. Dari 18 soal, peserta hanya menjawab benar 6 soal. Lebih dari 50\% soal tidak terjawab sehingga dapat dikatakan kemampuan dan pengetahuan akan padanan kata dalam bahasa Indonesia perlu mendapat perhatian khusus. Dari analisis jawaban peserta, soal yang terjawab adalah yang berhubungan dengan bidang komunikasi, baik melalui media cetak maupun elektronik. Berdasarkan tinjauan sosiolinguistik, dapat dilihat bahwa penggunaan kata-kata asing sebagai pengganti bahasa Indonesia merupakan salah satu gejala yang tidak dapat dihindari. Media sosial merupakan sarana efektif dalam memperkenalkan kata-kata dari negeri sendiri, seperti galat, binatu, daring, nirkabel, pindai dan tautan sebagai bukti keberhasilan para peserta dalam menjawab pertanyaan kuis. Katakata tersebut kerap muncul di media sosial, sebuah wahana yang tidak asing bagi kalangan remaja masa kini.

Dari beberapa penelitian yang telah dilakukan, perbedaan yang tampak pada penelitian ini adalah peneliti berusaha mencari tahu kemampuan memahami dan kekerapan mahasiswa dalam menggunakan padanan bahasa Indonesia dalam kegiatannya sehari-hari, baik dari ragam lisan maupun ragam tulis. Dengan adanya penelitian ini, dapat ditemukan hasil yang dapat menggambarkan penggunaan padanan kata di kalangan mahasiswa.

Penelitian ini memiliki urgensi (keutamaan) dalam bidang kebahasaan, khususnya dalam penggunaan bahasa Indonesia. Padanan kata dalam Bahasa Indonesia menjadi hal yang penting untuk diketahui agar perbendaharaan kosakata yang dimiliki dan digunakan masyarakat, khususnya mahasiswa bertambah, sehingga pesona bahasa Indonesia tidak akan kalah dibandingkan dengan kosakata bahasa asing.

Secara teoretis, hasil penelitian ini dapat menambah khazanah pengetahuan dalam bidang linguistik, khususnya tentang kosakata Bahasa Indonesia. Secara praktis, hasil penelitian ini dapat 
bermanfaat bagi: a. Dosen; Hasil penelitian dapat dijadikan tolok ukur dalam memetakan kemampuan memahami padanan kata di kalangan mahasiswa. b. Mahasiswa; Hasil penelitian dapat dijadikan sebagai bahan evaluasi diri mahasiswa dalam memahami padanan kata. c. Peneliti selanjutnya; Hasil penelitian ini dapat dijadikan referensi awal untuk melakukan penelitian lanjutan yang lebih mendalam terkait dengan padanan kata.

\section{Metode}

Metode yang digunakan dalam penelitian ini adalah metode deskriptif kualitatif. Penelitian deskriptif kualitatif adalah metode penelitian yang bertujuan untuk menggambarkan secara utuh dan mendalam tentang realitas sosial dan berbagai fenomena yang terjadi di masyarakat yang menjadi subjek penelitian sehingga tergambarkan ciri, karakter, sifat, dan model dari fenomena tersebut (Sanjaya, 2015). Dapat disimpulkan bahwa metode deskriptif kualitatif merupakan suatu metode alam meneliti suatu objek atau permasalahan untuk menggambarkan infomasi mengenai objek tersebut secara apa adanya dan sesuai fakta yang terjadi.

Penelitian bertempat di salah satu universitas swasta di Jakarta Selatan dan Timur. Sasaran atau objek penelitian, yaitu Mahasiswa Program Studi Pendidikan Bahasa Indonesia dan Pendidikan Ekonomi. Dalam penelitian ini, objek mengisi angket melalui google form untuk mendapatkan informasi tentang penggunaan padanan kata bahasa Indonesia dan untuk mendapatkan informasi kekerapan mahasiswa menggunakan padanan kata bahasa Indonesia. Setelah data terkumpul dilakukan perhitungan secara kuantitatif dengan menggunakan teknik perhitungan sederhana. Selanjutnya data dideskripsikan.

\section{Hasil dan Diskusi}

Mengacu hasil pengolahan data, secara deskriptif data penelitian dapat dinyatakan dalam tabel 1 .

\begin{tabular}{|c|c|c|c|c|}
\hline No & Pertanyaan & Ya & Tidak & Jumlah \\
\hline 1 & Kata Online berpadanan dengan kata Daring & $87,3 \%$ & $12,7 \%$ & $100,00 \%$ \\
\hline 2 & Kata Drive True berpadanan dengan kata Lantatur & $98 \%$ & $2 \%$ & $100,00 \%$ \\
\hline 3 & Kata Gadget berpadanan dengan kata gawai & $89,9 \%$ & $10,1 \%$ & $100,00 \%$ \\
\hline 4 & Kata Subscribe berpadanan dengan kata berlangganan & $84 \%$ & $16 \%$ & $100,00 \%$ \\
\hline 5 & Kata Review berpadanan dengan kata Ulasan & $78,4 \%$ & $21,6 \%$ & $600,00 \%$ \\
\hline 6 & Kata Link berpadanan dengan kata Tautan & $82,4 \%$ & $17,6 \%$ & $100,00 \%$ \\
\hline 7 & Kata Laundry berpadanan dengan kata Penatu & $98 \%$ & $2 \%$ & $100,00 \%$ \\
\hline 8 & Kata Barcode berpadanan dengan kata Kode Batang & $90,8 \%$ & $9,2 \%$ & $100,00 \%$ \\
\hline 9 & Kata Screenshot berpadanan dengan kata Tangkapan Layar & $90,5 \%$ & $9,5 \%$ & $100,00 \%$ \\
\hline 10 & Kata Selfie berpadanan dengan kata Swafoto & $93,5 \%$ & $6,5 \%$ & $100,00 \%$ \\
\hline 11 & Kata Slide berpadanan dengan kata Salindia & $96,1 \%$ & $3,9 \%$ & $100,00 \%$ \\
\hline 12 & Kata Lotion berpadanan dengan kata Calir & $97,1 \%$ & $2,9 \%$ & $100,00 \%$ \\
\hline 13 & Kata Hacker berpadanan dengan kata Peretas & $89,9 \%$ & $10,1 \%$ & $100,00 \%$ \\
\hline 14 & Kata Maintenance berpadanan dengan kata pemeliharaan & $56,5 \%$ & $43,5 \%$ & $100,00 \%$ \\
\hline 15 & Kata Scan berpadanan dengan kata pindai & $83,3 \%$ & $16,7 \%$ & $100,00 \%$ \\
\hline 16 & Kata Forward berpadanan dengan kata Teruskan & $46,4 \%$ & $53,6 \%$ & $100,00 \%$ \\
\hline 17 & Kata Email berpadanan dengan kata surel & $91,2 \%$ & $8,8 \%$ & $100,00 \%$ \\
\hline 18 & Kata Contact Person berpadanan dengan kata Narahubung & $89,9 \%$ & $10,1 \%$ & $100,00 \%$ \\
\hline 19 & Kata Workshop berpadanan dengan kata Lokakarya & $96,7 \%$ & $10,3 \%$ & $107,00 \%$ \\
\hline 20 & Kata Skip berpadanan dengan kata melewati & $80,4 \%$ & $19,6 \%$ & $100,00 \%$ \\
\hline
\end{tabular}

Sumber: data diolah

Berdasarkan tabel di atas, tampak bahwa mahasiswa belum memiliki kemampuan memahami padanan kata yang tepat dalam bahasa Indonesia. Hal ini dibuktikan dengan masih banyaknya mereka menggunakan dan mendengar bahasa Inggris dibandingkan bahasa Indonesia. Sebaran data paling banyak adalah pada padanan kata Laundry, Drive True yang menunjukkan angka 98\% dan paling sedikit adalah kata maintanance yang menunjukkan angka 56\%. Angka terendah saja masih di atas 50\%, hal ini menunjukkan kurangnya penggunaan padanan bahasa Indonesia di ruang publik pada kalangan mahasiswa.

Persebaran penggunaan padanan kata pada mahasiswa adalah sebagai berikut, 1) ada 87\% mahasiswa yang menggunakan kata Online dibandingkan daring. Ini merupakan angka yang sangat tinggi dan membuktikan lemahnya penggunaan padanan kata bahasa Indonesia di kalangan mahasiswa. 2) terdapat 98\% mahasiswa yang menggunakan kata Drive True dibandingkan Lantatur dalam kehidupan sehari-hari. Hal ini membuktikan masih sangat kurangnya pemahaman dan penggunaan bahasa Indonesia di ruang publik, khususnya di bidang penyediaan layanan makanan cepat saji atau pelayanan lainnya. 
Penyedia layanan kurang bahkan tidak memberikan padanan dalam bahasa Indonesia sehingga pengunjung terbiasa menggunakan istilah dalam bahasa Inggris. Hal ini juga turut memicu lemahnya penggunaan padanan bahasa Indonesia pada kata Drive True. 3) Terdapat 89\% responden terbiasa menggunakan kata Gadget untuk menyebut gawai. Kata Gawai sebenarnya sudah banyak digaungkan di masyarakat dengan banyak iklan layanan masyarakat dan unggahan di jejaring sosial pemerintah. Hanya saja, pembiasaan yang kurang dilakukan mengakibatkan sulitnya mengubah kata Gadget menjadi gawai di lingkungan masyarakat, khususnya mahasiswa. 4) Subscribe merupakan salah satu kata yang sedang banyak diucapkan oleh kalangan milenial, khususnya mereka yang menggunakan aplikasi berbagi video YouTube. Pengguna YouTube akan menganggap semakin banyak subscribe pada kanalnya, maka akun tersebut akan semakin baik dan terkenal. Hal inilah yang menjadi penggunaan padanan kata subscribe lebih banyak dibandingkan berlangganan. Tercatat terdapat $84 \%$ responden menggunakan kata subcribe dibandingkan berlangganan.

5) Semakin maraknya penggunaan media digital di kehidupan sehari-hari membuat masyarakat lebih waspada dalam berkomunikasi dan bertransaksi. Biasanya, sebelum membeli atau mendatangi tempat, mereka akan melihat ulasannya terlebih dahulu. Setidaknya, ada $21 \%$ responden terbiasa menggunakan kata ulasan dibandingkan kata review. 6) terdapat $82 \%$ responden yang terbiasa menggunakan kata link dibandingkan padanan katanya yakni tautan. Semakin banyaknya kebutuhan masyarakat mengakses situs web, menjadikan beberapa istilahnya banyak digunakan termasuk kata link atau tautan. Sayangnya lebih banyak yang menggunakan kata link dibandingkan kata tautan.

7) Pengguna kata Laundry sebanyak $98 \%$ dibandingkan kata penatu. Bahkan ada responden yang terbiasa menggunakan kata binatu. Binatu merupakan bentuk tidak baku dari penatu. 8) Masih banyak responden yang menggunakan kata selfie untuk swafoto. Terbukti $93 \%$ responden masih menggunakan kata selfie untuk menyatakan berfoto secara mandiri.

9) Terdapat $96 \%$ untuk penggunaan kata slide dibandingkan padanannya yakni salindia. Terlalu banyak penggunaan kata slide di lingkungan akademik membuat responden terbiasa mendengar dan mengucapkannya dibandingkan kata salindia. Tentunya hal ini harus diminimalkan mengingat lingkungan akademik adalah salah satu tempat yang harus menggunakan bahasa Indonesia yang benar. 10) Begitu pula dengan kata Workshop, terdapat 96\% responden pengguna kata workshop dan sisanya menggunakan kata lokakarya. Kata yang biasa digunakan di lingkungan akademik dan sudah saatnya dilakukan pembiasaan menggunakan padanan kata bahasa Indonesia.

\section{Simpulan}

Berdasarkan hasil dan diskusi, dapat disimpulkan bahwa: 1) Masih rendahnya penggunaan padanan kata bahasa Indonesia di kalangan mahasiswa, terbukti setidaknya ada 98\% responden yang lebih sering mendengar dan menggunakan kata Laundry dibandingkan kata penatu. 2) Lemahnya pembiasaan penggunaan padanan kata di lingkungan akademik dan masyarakat. Hal ini dibuktikan dengan beberapa kata yang lekat dengan lingkungan akademik dan masyarakat masih menggunakan kata dalam bahasa asing, padahal padanan katanya sudah ditemukan dan disosialisasikan oleh pihak berwenang melalui media sosial.

\section{Ucapan Terima Kasih}

Terima kasih kepada LPPM Universitas Indraprasta PGRI dan pihak-pihak yang telah memfasilitasi serta membantu terselesaikannya penelitian ini. Semoga hasil penelitian ini dapat berguna untuk para pembaca.

\section{Daftar Rujukan}

Chamalah, Evi. "Pengaruh Penggunaan Bahasa Inggris terhadap Makna Asosiatif pada Nama Badan Usaha di Kota Semarang”. Semarang: Universitas Islam Sultan Agung. https://adoc.tips/pengaruhpenggunaan-bahasa-inggris-terhadap-makna-asosiatif-.html, 2018.

Hudaa, S. "Transliterasi, Serapan, dan Padanan Kata: Upaya Pemutakhiran Istilah dalam Bahasa Indonesia." SeBaSa: Jurnal Pendidikan Bahasa dan Sastra Indonesia 2.1 (2019). http://ejournal.hamzanwadi.ac.id/index.php/sbs/article/view/1346/775 diunduh pada 7 Maret 2020

Hudaa, Syihaabul. "Peranan Lingkungan dalam Pemelajaran Bahasa Indonesia sebagai Bahasa Kedua." Seminar Internasional di UIN Syarif Hidayatullah Jakarta (2018). 
50 The Ability to Understand Indonesian Language Equivalents Among Private Universities Students in Jakarta

Maryani, Zulisih. "Padanan Kata Asing-Indonesia dalam Bidang Seni”. Yogyakarta: BP ISI Yogyakarta, (2017) http://digilib.isi.ac.id/id/eprint/2261

Sanjaya, Wina. Penelitian pendidikan. Jakarta: Prenadamedia Group, 2015.

Sanusi, Siti Saleha. "Padanan kata kerja Bahasa Jerman: Satu analisis ketepatannya ke atas makna ayat." Masters thesis, University of Malaya, (2016) http://studentsrepo.um.edu.my/id/eprint/6491

Sudibyo, Alexander. "Analisis Pemilihan Padanan Kata Science dalam Rangka Penyempurnaan Konsep RUU Keantariksaan.” Jurnal Analisis dan Informasi Kedirgantaraan 5.1 (2008): 32-39. http://jurnal.lapan.go.id/index.php/jurnal_ansis/article/view/3

Wiyanti, Endang. "Kemampuan Memahami Padanan Kata Bahasa Indonesia pada Peserta Kuis Olimpiade Indonesia Cerdas Season 2 di Rajawali Televisi." DEIKSIS 08.03 (2016): 247 - 255. https://journal.lppmunindra.ac.id/index.php/Deiksis/article/view/828 diunduh 8 Maret 2020. 